\title{
DECREE IN PARTITION OF THE HALF BREED TRACT IN I.EE COUN'TY, IOWA, 1840
}

\author{
Rendered by Citarles Mason, Chief Justice of the \\ Territorial Supreme Courte dr Iowa ${ }^{1}$
}

PROCEEDINGS IN PAR'IITION before the District Court within and for the County of Lce and Territory of Iowa on the Eighth day of May A. D. 1841, in a certain cause wherein Josiah Spaulding et al were plaintiffs and Euplrosine Antaya et al were defendants, be it remembered that heretofore, to-wit: On the Fourteentl day of April A. D. 1840, Josiah Spaulding et al filed in the office of the Clerk of said District Court a certain petition in partition in the words and figures following, to-wit:

April 'Term 1840: To the District Court of Lee County in the 'Territory of Iowa. Your petitioners Josiah Spaulding, Atchibald Gamble, Patrick Walsh, Etienne Prevost, John and Edward Walsh, H. K. OrtIey, Green Erskine, Joseph Ridgway, assignee of George Patch, Herman C. Cole, Stephen Gore, John B. Sarpy, Edmuind H. McCabe, Hugh 'Tumelty, James R. McDonald, Joseph W. Walsh, John O'Rourke, Antoine Garcia and Margaret his wife, Angilique Mattabone, formerly La Guthrie, Michael Tesson of the City of St. Louis and the State of Missouri, Heirs and legal representatives of Otis Reynolds late of the City of St. Louis, deceased, Heirs and legal representatives of J. A. H. Palmer late of St. Louis deceased, George H. Grossman of the United States Army, and Antoine Le Claire of Davenport in the Territory of Iowa, represent that they have a legal title to and are seized in fee simple of twenty-three and one-third full shares; and five thousand one hundred and thirty-five acres of land in that tract of land commonly called the Half Breed 'Iract situated in Lee county aforesaid, lying between the Mississippi and Des Moines rivers, bounded on the North by a line drawn from the North West corner of the State of Missouri, Fast to the Mississippi River and containing one hundred and nineteen thousand acres more or less, together with one full share and one-sixth of a full share in Keokuk, a village situated on said tract. 'The pitrticular interest here claimed are as follows, to-wit:

1Our institution has by gift come into the ownerslip of a vast collection of correspondence of the liate Charles Mason. Of the Iowa portions none of the collection is of greater importance than that which is directly or remotely connected with the Half Breed 'Tract. To provide a starting point for the publication of part or all of this group of Judge Mason's papers, we herewith publish the proceedings in partition of the lands, the decree having been signed by Jurlge Mlason as presicling judge. This decree supplies the names of some of the half breed beneficiaries of the Washington Treaty of August 4, 1824. On the titles of these and of other persons named with them, rest all the present land titles with a few exceptions in the tract. Each exception is a problem for the lawyer and historian rivaling in interest and intricacy the chain of title descent from the decree. We have followed the style of the original decree as certified by the clerk of the District Court of Lee County.-Editor. 
Josiah Spaulding claims one-half of a full share under Margaret Antaya, a half breed of the Suc and Fox nations of Indians, also onehalf of a full share under Theotist Prevost, a half breed of the same nations of Indians, also one-eighth of a full share under Mary Giard it half breed of the same nation, also one-fourth of a full share under Francis Blondeal a half breed as aforesilid. Atchibald Gamble claims one-half of a full share under Margaret Antaya a half breed as aforesaid, also one-half of a full share under Theotist Prevost, a half breed as aforesaid, also one-eighth of a full share under Benjamin La Guthrie, a half breed as aforesaid. Patrick Walsh claims one-half of a full share under Isadore Antaya, a half breed as aforesaid, also onc-half of a full share under Benjamin La Guthrie, a half breed as aforesaid. Etienne Prevost claims onc-half of a full share under Isadore Antaya, a half breed as aforesaid. John and Edward Walsh claim the twothirds of a full share under Maria Hebert, a half breed as aforesaid, also three-fifths of a full share uncler Pierre Jeaudron, a half breed as aforesaid, also one-eighth of a full share under Francis Blondeau, a half breed as aforesaid, also three hundred and twenty acres of land under Isaac Antaya, a half breed as aforesaid, being onc quarter of a claim, also six hundred and forty acres of land under Peter Courville, being one-half claim. H. K. Ortly claims the two-fifths of a full share under Pierre Jeaudron, a half breed as aforesaid. Green Erskine claims the two-thirds of a full share under Lisette Giard, a half breed as aforesaid, also the one-eighth of a full share under Francis Blondeau, a half breed as aforesaid, also one full share under Francis Ontis, a half breed as aforesaid. Joseph Ridgway trustee of George Patch, claims one-third of a full share under Lisette Giard, a half breed as aforesaid. Herman C. Cole claims the one-fourth of a full share under Francis Blondeau, a half breed as aforesaid. Stephen Gore clitims the one eighth of a full share under Francis Blondeau, a half breed as aforesaid. John B. Sarpy claims the one-third of a full share under Catherine Blondeau, a half breed as aforesaid. Hugh 'Tumelty claims one full share under Elizabeth Honori alias Shultz, a half breed as aforesaid. James R. McDonald claims one full share under Theresse Maillott, a half breed as oforeşaid. Joseph W. Walsh claims one half of it full share under Margaret Carpenter, now Garcia, a half breed as aforesaid, also the one-half of a full share under Angelique Ia Guthrie, now Mattabon, a half breed as aforesaid. John O'Rourke claims the onehalf of a full share under Banjamin La Guthrie, a half breed as aforcsaid. Antoine Garcia and Margaret his wife claim the one half of a full share in right of said wife, formerly Margaret Carpenter a half breed as aforesaid. Angelique la Guthrie, now Nattabon, claims the one-third of a full share in her own right. Michael Tesson claims four thousand acres more or less and a full share in the town of Keokuk under Lisette St. Joan, alias La Perche a half breed as aforesaid, being one full share. Heirs and legal representatives of Otis Reynolds deceased claim the one-third of a full share under Maria Herbert, a half 
breed as aforesaid, also the one-eighth of a full share under Francis Blondeau, a half breed as aforesaid. Heirs and legal representatives of J. A. H. Palmer deceased claim the one-third of a full share under Catharine Blondeau, a half breed as aforesaid.' George H. Crossman claims the one-half of a full share under Christopher Antaya, a half breed as aforesaid, also the one-third of a full share under Isaac Antaya, a half breed as aforesaid, also one hundred and seventy-five acres of land and one-sixth of a full share in the town of Keokuk under Maria Antaya, a half breed as aforesaid. Antoine Le Claire claims one full share under Emily Lucia, a half breed as àforesaid, also one full share under Baptiste Join, a half breed as aforesaid, also one full share under Thomas Abbott, a half breed as aforesaid, also one full share under Catharine Morgan, a half breed as alforeshid, also one full share under Charlotte Jarrith, a half breed, also onel full share under John Morgan, a half breed, also one full share under Catharine Watts, a half breed, also one under Margaret Le Claire! his wife, a half breed of the Sac and Fox nation of Indians.

And your petitioners further represent that Euphrosine Antaya, Elizabeth Hunt, Eliza O. Perkins (late Guildersleeve formerly Johnson) Mary L. Murdock, formerly Johnson, Rosella O, Gliem, formerly Johnson, James Muir, Thomas Connelly and Betsy! Farrar their heirs or assigns, and other persons whose names and places of residence are unknown to your petitioners, are tenants in common with your petitioners in said premises; your petitioners therefore pray that partition of said lands may be made; or if the same cannot be done without manifest injury, then that such other proceedings may be had in the premises as are authorized by law.

Reid \& Johnston, Attorneys for Petitioners.

To which petition was the following affidavit, to-wit: "Ed. Johnston on his solemn oath says that the facts set forth in the foregoing petition are true to the best of his knowledge and belief;

Sworn and subscribed this 14th day of Aprill, 1840.

Ed, Johnston.

John H. Lines, Clerk Dist. Court.

To which said petition and affidavit was attached the following praecipe, to-wit:

Territory of Iowa, Lec County, Sct.-District Court, A pril 'Term 184.0.

Josiah Spaulding, Archibald Gamble, Patrick Walsh, Etienne Prevost, John \&. Edward Walsh, H. K. Ortley, Greon Erskine, Joseph Ridgway, assignes of George Patch, Herman C. Cole, Stephen Gore, John B. Sarpy, Edmund H. MeCabe, Hugh Tumelty, James R. McDonald, Joseph W. Walsh, John O'Rourke, Antoind Garcia \& Margaret his zoife, Angelique Mattabon formerly La Guthrie, Michael Tesson, Heirs and legal representatives of Otis Reynolds, deceased, Heirs and legal representatives of J.A.H. Palmer, deceased: George H. Crossman, 
and Antoine Le Claire, vs. Euphrosine Antaya, Elizabeth Hunt, Eliza O. Perkins late Gildersleeve formerly Johnson, Mary L. Murdock formerly Johnson, Rosella O. Gliem formerly Johnson, James Muir, 'Thomas Connelly and Betsy Farrar.

Petition for Partition. The clerk of the court will issue a summons in the above case returnable according to law. Which said petition, affidavit and praecipe were endorsed by the clerk as follows, to-wit: "Filed April 14th, 1840.

John H. Lines, Clerk Dist. Court"

Afterwards, to-wit, on the day of filing the petition aforesaid the following writ of summons was issued from the office of the Clerk of the Court aforesaid, to-wit:

'Territory of Iowa, Lee County, Sct. The United States of America to the Sheriff of said County greeting. You are hereby commanded to summon Euphrosine Antaya, Elizabeth Hunt, Eliza O. Perkins, late Guildersleeve formerly Johnson, Mary L. Murdock formerly Johnson, Rosella O. Gliem formerly Johnson, James Muir, Thomas Connelly and Betsy Farrar if to be found in your County, to be and appear before the Dist. Court for the said County on the first day of the next term thereof to be begun and holden within and for said County at the Court House in Fort Madison on the Fourth Monday of April instant, to answer Josiah Spaulding, Archibald Gamble, Patrick Walsh, Etienne Prevost, John and Edward Walsh, H. K. Ortly, Green Erskine, Joseph Ridgway, assignee of George Patch, Herman C. Cole, Stephen Gore, John B. Sarpy, Edmund H. McCabe, Hugh Tumelty, James R. McDonald, Joseph W. Walsh, John O'Rourke, Antoine Garcia and Margaret his wife, Angelique Mattabon formerly La Guthrie, Michael 'Tesson, Heirs and legal representatives of Otis Reynolds, dec'd, Heirs and legal representatives of J. A. H. Palmer, dec'd, George H. Crossman and Antoine Le Claire in a petition for partition exhibited against them by the persons last aforesaid. Hereof fail not and have you there this writ.

(SEAL) Witness the Hon. Charles Mason, Judge of our said Court and sealed with the temporary seal thereof this 14th day of April A. D. 1840 .

John H. Lines, Clerk Dist. Court.

Afterwards, to-wit, on the 16th day of April 1840, the sheriff of said County returned said writ of summon endorsed as follows, to-wit: The within named defendants not found April 16, 1840. Sheriffs fees $\$ 5.00$

B. W. Gillock, Sheriff.

Afterwards, to-wit, at the April Term A. D. 1840 of said Dist Court, to-wit, on the 27 th day of April A. D. 184\%, the following proceedings were had, to-wit:

Josiah Spauling et al vs. Euphrosine Antaya et al. Petition for Partition. 
And now comes the plaintiffs by Reid \& Johnston, their attorneys, and move the Court for a continuance and an order of publication as the law direct whercupon the same is ordered by the Court. Afterwards, to-wit, at the October Term of said Dist. Court 1840, to-wit, on the 9th day of October A. D. 1840, the following proceedings were had, to-wit: On this day came the said petitioners by Reid \& Johnston, their attorneys, and made proof of the publication of the notice ordered to be made at the April 'Term 1840 of said Court, which notice and proof are in the words and figures following, to-wit:

Territory of Iowa, Lee County, Sct. Josiah Spaulding et al vs. Tuphrosine Antaya et al. Dist Court for said County, April Term 1840. Petition for Partition.

Notice is hereby given that a petition was filed on the 1.th clay of April A. D. 1840, in the Dist. Court of Lee County a foresaid, by Josiah Spaulding, Archibald Gamble, Patrick Walsh, Etienne Prevost, John and Fidward Walsh, H. K. Ortly, Green Erskihe, Joseph Ridgway, assignee of George Patch, Herman C. Cole, Stẹphen Gore, John B. Sarpy, Edmund H. McCabe, Hugh Tumelty, James R. McDonald, Joseph W. Walsh, John O'Rourke, Antoine Garcia and Margaret his wife, Angelique Mattabon formerly I.a Guthrie, Michael 'lesson, Heirs and legal representatives of Otis Reynolds, deceased, Heirs and legal representatives of J. A. H. Palmer dec'd, George H. Crossman, Antoine Le Claire as petitioners and against Euphrosine Antaya, Elizabeth Hunt, Eliza O. Perkins (late Guildersleeve formerly Johnson) Mary I.. Murdock formerly Johnson, Rosella O. Gliem formerly Johnson, James Muir, 'Thomas Connelly \& Betsy Farrar as defendants and is now pending, wherein said petitioners pray that a partition be made of the following real estate, to-wit: All that tract of land commonly called the "Half" Breed Tract", situated in Lee County aforesaid, lying between the Mississippi and Des Moines rivers, bounded on the North by a line drawn from the Northwest corner of the State of Missouri; east to the Mississippi River and containing one hundred and ninetecn thousand acres more or less, and the said defendants and all other persons interested in said property herein described are required to appear and answer to said petition on or before the next term of the Dist. Court of Lee County aforesaid, to be begun and holden on the first Monday in October next, or the proceedings had in the cause thereafter will be binding and conclusive on them forever. John H. Lines, Clerk Dis. Court. Reid \& Johnston, Attorneys for Plaintiffs.-Territory of Iowa, Lee County, ss. Personally appeared before me John H. McKenny who being duly sworn upon his oath deposes and says that he is the publisher of the "Iowa 'Territorial Gazette and Advertiser" published at the City of Burlington, the seat of Government of said Territory, and that the above notice hereto attached has been published in said paper'for twelve successive weeks immediately preceding this date. J. H. Mckenny.

Sworn and subscribed before me this 3d day of October 1840. John H. Lines, Clerk. 
Which said notice and affidavit were endorsed as follows, to-wit: "Filed Oct. 9, 1840. John H. Lines, Clerk by Edwin Guthrie, Deputy."

Afterwards, to-wit, on the day and year last aforesaid the following proceedings were had, to-wit: Josiah Spaulding et al vs. Euphrosine Antaya et al. In Chancery. This day came Mary Palmer, Hannah Evans, Elizabeth Wheeler, Sarah Goff Rayner, Thomas Palmer, and Henry G. Palmer by their attorneys Reid \& Johnston, and moved the Court that their names may be inserted in the petition for partition in the case as the legal heirs and representatives of Samuel Palmer, which is ordered by the Court.

Afterwards, to-wit: On the 10th day of October A. D. 1849, the following proceedings were had to-wit: Josiah Spaulding et al vs. Euphrosine Antaya et al. In Chancery. And now on this day came Charles Thompson, Joln W. Smith and Dalyel Smith by their attorney Alfred Rich and move the Court that they may be made defendants in this causc and that they have until next Tuesday to file their answer which is ordered accordingly.

Afterwards, to-wit, on the 12th day of October A. D. 1840, the following proceedings were had, to-wit: Spaulding et al vs. Antaya et al. Petition for Partition. And now comes Edward Manning by his attorney Wm. Henry Starr and with leave of the Court, enters his appearance to the petition of said plaintiffs and time is given him until the next term of this Court to file his answer.

Afterwards, to-wit, on the day and year last aforesaid the following proceedings were had to-wit: Spaulding et al vs. Antaya et al. Petition for Partition. And now comes William MeDaniel and Uriel Wright by their attorney H. W. Starr, and enter their appearance to plaintiffs petition and on motion of their said attorney it is ordered by the Court that time be extended to them until the next term of this Court to filc their answers.

Also the following procecdings, to-wit: Spaulding et al rs. Antaya et al. Petition for Partition. And now comes Henry ' $\mathrm{C}$. Darrah by W. H. Starr his attorney and enters his appearance as defendant to plaintiffs petition, and on motion it is considered by the Court that he have until the next term of this Court to file his answer.

Afterwards, to-wit, on the 13th day of October A. D. 1840, the following proceedings were had, to-wit. Josiah Spaulding et al vs. Euphrosine Antaya et al. Petition. And now on this day this cause came up for hearing and thereupon came Jehise Wright, William McDaniel and Henry 'T. Darralı by their attorney Wm. Henry Starr, and entered their appearances to the petition of the foregoing plaintiffs and asked of the Court further time to file their answers until the next term of this Court, whereupon it was ordered by the Court that the above suit stand continued and that all who have a right to become defendant to the same have until the first day of the next term of this Court to answer the plaintiffs petition. 
Afterwards, to-wit, on the 13th day of Oct. A, D. 1840, Eliza Hunt, Rosella O. Gliem formerly Johnson, and Edgar H. Gliem her husband, Mary L. Murdock formerly Johnson, and Francis B. Murdock her husband and Eliza Perkins, late Guildersleeve formerly Johnson, and David Perkins her husband, some of whom are named as defendants in said petition, filed in the office of the Clerk of said Dist. Court their answers to said petition in the words and figures following, to-wit: District Court of Lee County, October Term A. D. 1840! Josiah Spaulding et al vs. Euphrosine Antaya et al. Partition. Eliza Hunt and Rosella O. Gliem formerly Johnson and Edgar $H$ Gliem her liusband, Mary. L. Murdock formerly Johnson and Francis B. Murdock her husband and Eliza Perkins, late Guildersleeve formerly Johnson and David Perkins, her husband, some of whom are named as defendants in the above titled cause came into Court by Reid \& Johnston thcir attorneys, and state the amount of interest which they hold in the Half Breed lands in Lee County, to be as follows, to-wit: Eliza Hunt is entitled to one full share or portion in these lands in her own right, she being a half breed of the Sac or Fox nation of Indians. Rosella $O$. Gliem and Edgar H. Gliem are entitled to one full share or portion in said lands in right of the said Rosella, she being a half breed of said tribe of Indians. Mary L. Murdock and Francis B. Murdock are entitled to one full share or portion in these lands by right of said Mary, she being a half breed of said tribe of Indians. Eliza Perkins and David Perkins are entitled to one full share in these lands in right of said Eliza, she being a half breed of said tribe of Indians. Reid \& Johnston, Attorneys for E. Hunt and others.

Which said answer is endorsed in the words and figures following, to-wit: Filed Oct. 13, 3840. John H. Lines, Clerk D. C.

$\Lambda$ fterwards, to-wit, on the 12th day of March 184.1, William Phelps, E. D. Ayres, William Gillis, Henry McKee, James L. Schoolcraft, Samucl Abbott, Abraham Wendall, G. V. Denniston, John C. Ward, Wilson L. Overall and John Wright, by their attorneys, Reid \& Johnston, filed in the office of the Clerk of said Dist. Court their answer to the petition aforesaid, in the words and figures following, to-wit: District Court l.ee County-April 'Term 1841. Josiah Spaulding et al vs. Euphrosine Antaya et al. Partition. William Phelps, Ebenezer D. Ayres, William Gillis, Henry McKee, James I. Schooleraft, Samuel Abbott, and Abralaim Wendall, Wilson I. Overall, John Wright, Gerret V. Deniston and Johı C. Ward came into Court by Reid \& Jolunston, their attorneys, and state the amount of interest which they hold in the Half Breed lands in Lee County to be as follows, to-wit: William Phelps claims to be cntitled to one full shatre or portion in these lands in right of a She-il-wa a half breed of the sac \& Fox nations of Indians as will appear by his conveyance filect: William Plielps claims to be entitled to one full share or portion in these lands in right of Mack-tal-wa a half breed of the Sac \& Fox nations of Indians as' will appear by his conveyance filed. Ebenczer D. Ayres claims to be entitled to all the right; 
and interest of Eustace Cardinal, being one-half share, the son of Elizabeth Cardinal, formrely Elizabeth Antaya, a half breed of the Sac \& Fox nations of Indians as will appear by an instrument of writing filed. William Gillis claims to be entitled to a full share or portion in their lands in right of Louis Buttattoth a half breed of the Sac or Fox tribe of Indiana as will appear by his conveyance filed. Henry McKee claims to be entitled to a full share or portion in these lands in right of Louis Gonville, a half breed of the Sac \& Fox nations of Indians as will appear by his conveyance filed. Wilson L. Overall claims to be entitled to one-third of a full share or portion of these half breed lands, in right of Isaac Antaya, a half breed of the Sac or Fox tribe of Indians as will appear by conveyance filed. Wilson L. Overall claims to be entitled to one hundred and seventy-five acres in the half breed tract and one-sixth of an interest or share or portion in the town of Keokuk under Peter Courville and Maria his wife, formerly Maria Antaya, she being a half breed of the Sac or Fox tribe of Indians as will appear by conveyance filed. John Wright claims to be entitled to onc-fourth of a full share or portion in the half breed lands in right of Charles Munar and Francoise, his wife formerly Francoise Hubert, through Isaac K. Camplell, the said Francoise being a half breed of the Sac \& Fox nations of Indians, as will appear by conveyance filed. Garrett $V$. Deniston claims to be entitled to one-half of a full share or portion in the half breed lands in right of Henry Deacon and Sophia, his wife, otherwise Sophia Dumont through La Graves, she, the said Sophin, being a lalf breed of the Sac or Fox nations of Indians as will appar by conveyance filed. John $\mathrm{C}$. Ward claims to be entitled to one-half of a full share or portion in the Half Breed lands in right of Henry Deacon and Sophia his wife, otherwise Sophia Dumont through La Graves, slıe, the said Sophia, being a half breed of the Sac or Fox tribes of Indians, as will appear by conveyance filed. James L. Schooleraft claims to be entitled to one-hialf of a full share or portion in the Half Breed lands in right of Louis Desoyner through George Johnston he, the said Desoyner being a half breed of the Sac or Fox nations of Indians, as will appear by conveyance filed. Samuel Abbott and Abraham Wendall claim to be entitled to one-half of a full share or portion in the half breed lands in right of Louis Desoynier through George Johnston, the said Desoynier being a half breed of the Sac or Fox tribes of Indians as will appear by the conveyance filed.

Reid \& Johnston, Attorneys for Phelps ancl Others.

Which said answer was endorsed as follows, to-wit:
Filed 12th March 1841.
O. S. X. Peck, Clerk.

Afterwards, to-wit, on the 26 th day of April A. D. 1841, to-wit, at the $\Lambda$ pril Term of said Dist. Court, the following answer to said petition was filed, to-wit: Ierritory of Iowa, County of I.ee-ss. District Court, April 'Term A. D. 184.1. Josiah Spaulding et al vs. Euphrosine Antaya et al, In Partition. And now comes Silas Andrews and Chris- 
topher R. Comstock, two of the unknown defendants against whom the said plaintiffs have filed their bill in the Dist. Court aforesaid, praying for a partition of certain lands commonly called the Half Breed lands, and the said Silas Andrews and Christopher $k$. Comstock claim one entire interest in said lands by purchase from: William McBride, the said McBride claiming by purchase from Pas-o-qua heirs and legal representative of Elizabeth Hunt deceased, which said Jilizabeth Hunt the saicl Andrews and Comstock claim to have been a half breed and entitled to a claim under the reservation made by the treaty for the benefit of the Sac \& Fox Indians. And the said Silas Andrews and Christopher R. Comstock by William H. Starr, their attorney, file herewith authentic copies of the conveyances under which they claim said interest and pray to be made parties to said partition. William Henry Starr, for Andrews \& Comstock.

Which said answer was endorsed as follows, to-wit: Filed April 26, A. D. 1841 .

O. S. X. Peck, Clërk.

Afterwards, to-wit, on the day and year last aforesaid the following order was made, to-wit:

Josiah Spaulding et al vs Euphrosine Antaya et al. Partition. On motion of Alfred Rich ordered by the Court that Jolm H. Lines, William Smith, D. Smith, John Smith, William IH. Smith and Charles Thompson have until Friday next to file their answer herein. Also the day and year aforesaid the following order/was made, to-wit:

Josiah Spaulding et al vs. Euphrosine Antaya et al. Partition. On motion of H. W. Starr ordered by the Court that Urial Wright, Henry T. Darrah, William McDaniel, and Edwin Manning have leave until Friday next to file their answer herein.

Afterwards, to-wit, on the 8th day of May $\Lambda$. D. 1841, the following order was made, to-wit:

Josiah Spaulding et al vs. Euphrosine Antayia et al. Partition. On motion of his attorney it is ordered by the Court that Hugh T. Reid be appointed Guardian ad litem for James Muir, one of the parties in this suit.

Afterwards, to-wit, on the dily and year last aforesaid the following procecdings were had, to-wit: Josiah Spaulding et al vs. Euphrosine Antaya et al. Partition. On this day came James $\mathrm{R}$. McDonald, Etienne Prevost, Green Erskine, P. Walsh, 'John O'Rourke, J. W. Walsh, Pierre Leon Mattabon, Michael Tesson, Antoine Garcia, Francis B. Murdock and Mary L. Murdock, E. H. Gliem and Rosella O. Gliem, parties to this suit and made proof of publidation of notice to take depositions to perpetuate testimony in this case.

Afterwards, to-wit, on the 8th day of May A. D. 184.1, the following answers to said petition were filed, to-wit: pist. Court Lee County. Spaulding et al rs. Antaya et al. The answer of John Smith, William Smith and Dalzel Smith, Charles 'Thompson, William Price, John H, 
L.incs, William H. Smith, Henry Browse and the heirs of Nathaniel Knapp to the petition of Spaulding et al vs. Antaya et al, in this Court for partition under the law of this Territory, of the land mentioned in said petition. By their attorney Rich respectfully represent that their claim to be owners and entitled to the shares and portions of said Half Breed Tract (the land mentioned in said petition) set forth in the annexed list or schedule of half breed claims. The proofs to the title to which claims are herewith filed and produced to Court and these respondent are willing that their said claims and the claims of the other parties herein may be adjudged by the Court of partition decreed according to law.

Rich, Attorney for Respondent.

John H. Lines claims one full share under Mi-seth-i-quois and also one full share under Susan Le Pant. William Smith, Dalzell Smith and John Smith claim three full shares, to-wit: One full share under Maswa-quois; one full share under Ha-la-we-quois and one full share under Wa-po-ke-chuck. Charles Thompson claims one full share under Pierre Antaya. William Price and his wife claim one full share in right of his wife. William H. Smith claims one and one and a half shares under Na-sa-wisset and Wa-pe-ke, also one share under Mo-wash. Henry Browse claims one-eighth of a full share. The heirs of Nathaniel Knapp claim two full shares and $7 / 8$ of a full sharc, to-wit: One-half of a full share under Wa-pa-shuck-o-mack, one full share under Ne-a-na-waqua, one full share under Pun Bogin, 7/8 of one share under Meloquoit- Which said answer and schedule were endorsed as follows, towit: Filed 8th May A. D. 1841.

O. S. X. Peck, Clerk.

The following answers and schedule were filed the day and year last aforesaid, to-wit: Spaulding et al vs. Antaya et al. For Partition. The answer of Augustus Gonville and Benjamin Franklin Messenger to the petition of Spaulding et al vs. Antaya et al in this Court for partition under the law of this Territory of the land mentioned in said petition by their attorney, Philip Veile, respectfully showeth that they claim to be entitled to the shares and proportions of said Half Breed tract (the land mentioned in said petition) set forth in the annexed list or schedule of the hatf breed claims the proofs of their title to which and anthentic copies of conveyances by which the same are held are herewith filed and produced to the Court and these defendants are willing that their sad claims and the claims of the said petitioners and the: other parties in this case should be decided and adjudged by the Court. and partition decreed according to law.

Philip Veile, Atty.

Schedule of half breed claims of Augustus Gonville and 13. F. Messerger. Augustus Gonville in his own right as a half breed one share. B. F. Messenger under Maunrice Gonville one share.

Philip Veile, Atty. 
Which said answer and schedule were endorsed as follows, to-wit: Filed 8th May 1841.

O. S. X. Peck, Clerk.

Afterwards, to-wit, on the day and year aforesaid the following answer to said petition was filed, to-wit: District Court I.ee County, April Term A. D. 1841. Iowa Territory. Spaulding et al vs. Antaya et al. For Partition. The answer of Abijah Fisher, D. W. Kilbourne and Henry S. Austin, D. W. Kilbourne and Henry S. Austin \& Edward Kilbourne and John Bertram, to the petition of Spaulding et al vs. Antaya et al in this Court for partition under the laws of this 'l'erritory of the land mentioned in said petition by their attorney, $H$. ' $I$. Reid, respectfully showeth that thcy claim to be entitled to the shares and proportions of said half breed tract (the land mentioned in said petition) set forth in the annexed list or schedule of half breed claims, the proofs of their title to which and authentic copies of the conveyances by which the same are held are herewith filed and produced to the Court. And these defendants are willing that their satid claims and the claims of the said petitioners and of the other partics in this case should be decided and adjudged by the Court and partition decreed according to law.

H. 'T. Reid, Attorney for Kilbourne and Others.

Schedule of lalf breed claims of Austin, Kilbourne, Kilbourne \& Bertram \& Abijah Fisher. Abijal Fisher under Battiste Bissonette three fourths of a share. D. W. Kilbourne \& Henry S. Austin under Maw-qua-kek-aha-wa Bissonete $1 / 4$ of a share, under Victory Pelhial one share. Edward Kilbourne under Puck-altini one half of a share. John Bertram under Les-eti-lasure one half of a share. Which satid answer and schedule were endorsed as follows, to-wit: Filed 8th May A. D. 1841 .

\section{O. S. X. Peck, Clerk.}

Afterwards to-wit, on the day and year aforesaid the following answers were filed Dist. Court April 'Ierm 1841. Spaulding et al vs. Antaya ct al. Partition. The answers of James Manning, Sheldon Norton, Edwin Mamning, Uriel Wright, Henry 'I. Darrah and William MeDaniel and Samuel Hearn to the petition filed by Spaulding et al vs. Antaya et al in this Court for partition under the laws of this Territory of the lands mentioned in said petition by Henry $W$. Starr their attorney, respectfully showeth that they claim to be entitled to the shares and proportions of said half breed tract (the land mentioned in said petition) set forth in the annexed list or schedule of half breed claims, the proof of their title to which and authentic copies of conveyances by which the same are held are herewith filed and produced to the Court and these defendants arc willing said clam and the claims of said petitioners and the other parties in the case should be decided and adjudged by the Court, and the partition decreed according to law. Henry W. Starr, Defts, Attorney. Schedule. Tames Manning and Shel- 
don Norton claims one-half of one full share in the Half breed Sac \& Fox rescrvation in right of the late Mary Courville late Mary Le Pointe, formerly Mary Antaya or Antayer, daughter of Pierre or Peter Antaya, a white man and a Sac or Fox woman. Edward Manning claims one-eighth part of two whole shares in said reservation in right of Percuma or Pecuma wife of Pour-pourte-quesa, the said Persuma or Pecuma being a half breed of the Sac \& Fox tribes of Indians and also sole heir of her deceased brother who was also a half breed Sac \& Fox. Samuel Hearn and James Manning .claim as jointly and equally interested one-half of the whole interest of Percuma or Pecuma the wife of Porquesa which she owned in her own right and one-half of her interest in right of and as sole heir of her deceased brother. Uriel Wright, Henry T. Darrah and William McDaniel claim as follows: One share in said half breed reservation in right of Felicite I.uisec or Iusouse before marriage, Felicite Du Pior afterwards married to Paul G. Luisec or Insouse; three fourths of one entire share in right of Mary Bell wife of Tunis Bell. 'The interest of Henry T. Barrah is five nineths of the above interest. The interest of Uriel $W$ right is one ninth of the foregoing interest. The interest of said Wright and McDiniel are three ninths as trustees. Henry W. Starr, Defts. Attorney. Which said answer is endorsed as follows, to-wit. Filed May 8th 184.1.

O. S. X. Peck, Clerk.

Afterwards, to-wit, on the day and year last aforesaid the following answer was made, to-wit: Dist. Court Lee County, April 'Term A. D. 1841. Josiah Spaulding et al rs. Euphrosine Antaya et al. Partition. Tames L.. Burtis, Margaret Farrar a minor under the age of 21 years by Sophia Farrar her guardian and Cyrus Peck came into court by Reid \& Johnston their attorney and state the amount of interest: which they hold in the half breed lands in I.ee County to be as fo!lows, towit: James I.. Burtis who claims through Stephen H. Burtis claims to be entitled to one full share or portion in these lands in right of 'Therese St. Amant formerly 'Therese Bell Freeman of the Sac \& Fox nations of Indians as will appear by his converance filed. Margaret Farrar by her Guardian Sophia Farrar, claims to be entitled to two full shares or portions in these lands in right of Betsy Farrar and Margaret Farrar, deceased, both half breeds of the Sac \& Fox nations of Indians, (the said Margaret who thus claims through Betsy and Mary Farrar her deceased sisters having been born since the treaty of 1824 by which said lands were reserved to sitid half breeds. Cyrus Peck claims to be entitled to one-eighth part or portion of a full share in these lands in right of Charlotte Carron a half breed of the Sac \& Fox nation of Indians through David W. Kilbourne and liarriett his wife as will appear by his converance filed, which said answer was enclorsed-Filed May 8th, 1841. O. S. X. Peck, Clerk. Reicl \& Johnstom, Attorneys for Burtis et al.

Afterwards, to-wit, on the day and year last aforesaid the following 
answer was filed, to-wit: Dist. Court-April T'erm A. D. 184.1. Josiah Spaulding et al vs. Euphrosine Antaya et al. Partition. 'Thomas Connelly and James Muir by H. T. Reid his guardian ad litem he being a minor under the age of twenty-one years, by Reid \& Johnston came into court and state the amount of interest which they hold in the half breed lands in Lee County to be as follows, to-wit: 'Thomas Connelly claims to be entitled to one full share or portion in said lands in his own right, he being a half breed of the Sac and Fox nations of Indians. James Muir by $H$. T. Reid his guardian ad litem claims to be entitled to one full share in said lands in his own right, he being a half breed of the Sac and Fox nations of Indians.

Reid \& Johnston, Attorneys for Connelly and Muir.

Which said answer was endorsed as follows, to-wit: Filed May 8th, 1841.

O. S. X. Peck, Clerk.

Afterwards, to-wit, on the day and year last aforesaid the following proceedings were had, to-wit: Spalding and others vs. Antaya and others. For Partition. The answer of Samuel Marsh, William E. Lee and Edward C. Delavan trustees under articles of association bearing date 22d October, 1836 (herewith filed Marked A) for the persons interested in said association agreeably to the stipulations and provisions therein set forth according to their respective interests to the petition filed by Spalding and others against Antnya and others in this Court for partition under the law of this Territory of the land mentioned in the petition by their attomey $F$. S. Key respectfully showeth that they and the persons interested in said association whom they represent, claim to be entitled to the shares and proportions of the said half breed tract the land mentioned in the said petition set forth in the annexed list or schedule of half breed claims the proofs to their title to which and authentic copies of the conveyances by which the same are held ar: herewith filed and produced to the Court and the defendints are willing that their said claims and the claims of said petitioners and of the other parties in this case should be decided and adjunged by the Court and partition decreed accoring to law.

\section{F. S. Key for Defts.}

List or scledule of Half Breed titles claimdd by Samucl Marsh, William E. I.ee and Edward C. Delavan 'Trustees for the New York claimants viz: An-all-pe-ah or Louisa Gates one portion. Pack-c-ta-chenier one portion. Wash-e-o-qua one portion. $A$-ke-ka-ni-nin one portion. Kew-e-qua one portion by Paw-ni-nine and Wa-pe-sha-qua-ma-qua. Ma-e-qua one portion. Ali-ket-tay one portion by Wa-pe-slia-qua-mak heir. Maw-ka-nuk one portion. Margaret Schomberger formerly Margaret Kratur one portion by Jean Schoonbenger heir and legal representative. Ket-was-sha one portion. Os-koothok-wall-co one portion. Wah-puk-way onc portion. Ma-she-pa-ke one portion. Pay-mi-pok-ko Bailitoh one portion. Lizeh-Mai-sin one portion. Tack-qual-a-kozh-kok 
one portion. Nash-pe-loui-Giavel one portion. Ma-she-Kee Raisin one portion. Wash-wa-co-De-Marav one portion. Elizabeth Antaya 2/3 by Eliza Cardinal and Eustace Cardinal heirs Thomas Abbott one share. Antoine Carron 3/4 by She-ka-na-shub-o-ma-tay and Angelica Carron heirs. Nali-mal-che-sale one portion by Wash-ke-sa son and heir. Mawni one portion by Aqua-take sole heir. Nas-se-wisset one portion. Wawa-ke one portion. Amelia De Louis, formerly Amelia Gonville, one portion. Mac-i-nah one portion. 'Tac-o-co one portion. Co-sho-be-ah one portion. Pu-pe-no-ah Gaulette one portion. Muk-c-oh one portion. Se-pe-nah one portion. Mary 'lolman, formerly Mary Dague one portion. Archangue Smith, formerly Archangue La Perche, one portion. Mary La Perch one portion by Archangue Smith and Brishnell and wife as heirs $A$ gatha La Perche-one portion by Archangue Smith and Brishnell and wife as heirs. Jane Muir one-half by $\Lambda$. Hood and wife as heirs Ma-chi-ni $2 / 3$ by Kis-kus and Ke-pis-qua as heirs. Ano-weone portion. Chi-pa-tot-i-qua one portion. Mas-se-pauh one portion. Sac-i-na-qua-pa one portion. Louisa Hood, formerly Louisa Muir, six hundred and forty acres of land and all their interest in Keokuk. Wawsai-to-quois and Pe-ah-two-te-nobe two portions. Kish-ke-tum one portion. Ke-wha-chi one by Mache-ne sole heir. Mak-a-sese one by Whto-was as heir. Ka-no-sa one portion by Na-mah-quah-taw-way sole heir. Nap-we one portion. She-peck one portion. O-co-sa one portion by Nap-wa and She-puk. Louisa Brishnell, formerly Louisa St. Jno La Perche, interest in Keokuk and all remaining interest in 4320 acres sold Christopher Antaya one-third Isaac Antaya one and one-half acres in Keokuk. Ke-shus one portion. Ka-pas-qua one portion. Na-che-na one portion. No-shaw-cun one portion. Mas-sa-se-pah one portion. Pash-ke-sole-chenier one half portion. Ut-tak-wa one portion. Asb-ecum E. Verbois one portion. Eustace Cardinal one portion. Unknown 1/2 by $A$. Smith. Do. 1/4 by F. Wilcox. F. S. Key for Defts.

\section{Articles of Association of the Neze York Company.}

This Indenture made the 22d day of October 1836 by and between the several persons whose names and seals are hereunto subscribed that is to say Joshua Aikin of Peoria and Isaac Galland of Commerce in the State of Illinois. Samuel Marsh, Benjamin F. Lee, William E. Lee, George P. Shipman, Henry Seymour all of the City of New York. Edward C. Delavan and Erastus Corning of the City of Albany. Whereas the said Joshua Aikin, Robert E. Little and Isaac Galland as agents, acting for and in behalf of the persons and parties hereinbefore named, have purchased certain lands situated lying and being in Wisconsin Territory between the Mississippi and Des Moines rivers part of the tract reserved in a certain treaty made on the 4th day of August 1824, between the United States and the Sac and Fox nation or tribes of Indians for the use of the Half Breeds of said nations or tribes of Indians, amounting in the whole to the sum of Twenty thousand dollars, the title to which said premises already. purchased is at present in the 
name of Eli Goodwin, Benjamin F. Lee, William E. Lee, Joshua Aikin and Isaac Galland, all parties hereto except the said Eli Goodwin and the said Aikin and Little are autlorized by the other persons and parties to these presents to invest a further sum in their discretion in the purchase of other portions of the same premises for and on account of the parties hereto as hereinafter defined from time to time as they may have opportunity, not exceeding in the whole the sum of Seventy-five thousand dollars including the above twenty thousand dollars-the title to all which premises is intended to be vested in the persons lereinafter named as joint tenants and not as teniants in common for the benefit of the parties herein mentioned.

NOW THEREFORE in consideration of the premises and in order to the more efficient, careful and advantageous management of the said property and for the greater facility in obtaining titles and ascertaining the quantity to which by such purchases the parties hereto may be entitled, and also in view of dividing the said premises among and to the several persons and parties who may be entitled to portions thereof by virtue of these presents in fee simple as tenants in common, the said parties hereto individually, and not jointly, each for himself his heirs, administrators, executors and assigns, covenants and agrees to and with the others and each of them and to and with them and each of their heirs, executors, administrators and assigns respectively as follows in respect to the said property so purchased or hereafter to be purchased, that is to say: "Firstly that the title to the property already purchased shall be conveyed to and duly invested in Joshua Aikin of Peoria and Isaac Galland of Commerce in the State of Illinois-Samuel Marsh and William E. Lee of the City of New York and Edward C. Delavan of the city of Albany as joint tenants and not as tenants in common in trust for the persons and parties interested therein as hereinafter defined and the title to all lands hereafter purchised or acquired by the said Aikin and Little in the said district of country shall be taken in the names of the said Trustees as joint tenants and not as tenants in common for the benefit of the parties hereto. And it is hereby mutually agreed and understood by and between the parties hereto that the interest and right of the said parties in and to the premises already purchased or hereafter to be purchased in pursuance hereof is as follows: That is to say, the whole into forty-eight shares or parts to be divided-The said Joshua Aikin and George P. Shipman jointly nineteen undivided forty eighth parts of the whole of said premises. The said George P. Shipman in his own right two undivided forty eighth parts. The said Isaac Galland eight undivided forty-eighth parts. 'The said Edward C. Delavan four undivided forty-eighth parts. The said Samuel Marsh two undivided forty-eighth parts. The said Benjamin F. Lee three undivided forty-eighth parts. The said William E. Lee six undivided forty-eighth parts. The said Erastus Corning two undivided forty-eighth parts. The said Henry Seymour two undivided fortyeighth parts. 
Secondly-and the parties hereto mutually covenant and agree to and with each other and each for himself to assume and pay on account of and for the purchase money expenses and improvements of said premises purchased and to be purchased in the following shares and proportions, that is to say-The said Isaac Galland eight forty-eighth parts of the whole. The said Edward C. Delavan eight forty-eighth parts. 'The said Samuel Marsh four forty-eighth parts. The said Henry Seymour four forty-eighth parts. The said B. F. Lee four forty-eighth parts. The said William E. I.ee eight forty eighth parts. The said Shipman and Aikin jointly four forty-eighth parts. 'The said George P. Shipman, in his own right, four forty eighth parts, and the said Erastus Corning four forty eighth parts, at such time as the same shall be required to meet the drafts and notes already made or which hereafter may be made by the said Aikin and Little or either of them or by any other agent or agents duly authorized on account of the premises already purchased or hereafter to be purchased under these presents and for this purpose the parties hereto respectively agree to accept and pay any draft or drafts which the said Trustees their agent or agents or their treasurer by them duly authorized and appointed shall at any time make upon them or any of them for their shares or interest is aforesaid.

Thirdly-And the parties hereto mutually covenant and agree that the said trustees or a majority of them shall have power and it shall be their duty-1. To cause the title to said lands and property to be thoroughly examined and established in such form of proceeding as they may be advised to be proper to protect the parties in interest against any loss or question on account thereof. 2. To cause the land purchased to be surveyed so that the exact quantity of land acquired by the parties hereto by the purchases already made or hereafter to be made as herein provided sball be ascertained. 3. Out of the said premises they shall cause to be surveyed and laid out such sites for towns, villages and cities as they may deem eligible and important for such purposes of all of which sites they shall have surveys and maps made and shall furnish each of the parties to these presents with copies thereof. They shall also cause the said property to be thoroughly examined in reference to water power and hydraulic privileges and such points as may be designated for such purposes they shall cause to be laid out in reference thereto and give account thereof to the parties to these presents as hereinafter provided. 4. And the said Trustees are hereby authorized to sell and convey from time to time as they may find opportunity any part of the lands so purchased on such terms as to payment and to take such securities for the purchase money or any part thereof as they shall think fit. 5. And the Trustees or a majority of them are also authorized to make all contracts and do all lawful things and acts that may be necessary or proper to carry into effect the object of this agreement and to promote the interest of the parties concerned in respect to the property purchased and every part 
thereof. 6. To employ, substitute and authorize such attorney or attorneys, agents and clerks, as may be necessary in executing the objects of this agreement and in the care and management of the said property and to allow them such compensation for their services as they may think fit. And in the event of the death of any of the said Trustees occuring before the trusts hereby created are perfected as herein provided, it is hereby mutually agreed that the surviving trustees shall designate some other person to supply the place of such decedant and the person so designated shall take the place of such decedant and execute faithfully all the duties hereby created in the same manner as such decedant if living might, could and ought to have done.

Fourthly-It is hereby mutually agreed by and between the parties hereto that the purchase money and the costs of improvements, taxes and assessments which have been paid or which at any time hereafter shall be paid by the said Trustees or any of them or by any of the parties hereto or by any other person interested in the avails of the said property are to be charged upon the said property and repaid out of the first proceeds thereof. And the proceeds of said property already purchased or hereafter to be purchased under this agreement and the proceeds of improvements made and to be made thereon or on any part thereof with all the rents, income and avails thereof howsoever arising or accruing after paying all expenses charges and disbursements for such improvements, taxes and assessments', care and management shall be first applied to the repayment of said purchase money by whomsoever paid or advanced with interest thereon and to the extinguishment of any sum which shall remain due and unpaid to any person or persons on account thereof-Which payment shall first be made to the persons who have paid most on the shares they are by this agreement bound to pay for till the balance of such payment shall be reduced to the same on each share and then pro rata upon all the shares till the whole cost is repaid so that the said premises and every part thereof may be free clear and unincumbered.

Fifthly-And it is mutually agreed that thei said Trustees shall and will in good faith to the best of their ability so manage and dispose of every part thereof as to promote the interest and advantage of all persons having a right to share in the avails and proceeds thereof, and that they shall and will after paying all just and proper expenses for taxes, assessments, surveys, agencies, counsel fees and improvements as aforesaid growing out of the proper care and management of the said property and every part thereof faithfully at all times and particularly on the first Monday of July in each and every year hereafter account for and pay to the parties hereto and each of them his or their assigns or personal representatives the portion of the avails and proceeds of the said property which he or they may be entitled to by virtue hereof and the said Trustees shall keep a regular book of account or accounts in which shall be entered all their purchases, sales and proceedings in respect to said property and every part thereof which books shall at 
all times be open to the inspection of any of the parties interested in the said premises. And they shall semi-annually on the first days of January and July in each and every year render an account of their doings to each of the parties interested if required.

Sixthly-And it is mutually covenanted and agreed also that whenever the Trustees shall have received or realized money enough from the sale and other disposition of the property to pay up and satisfy the whole amount of the purchase money and improvements and interest thereon o,er and above the taxes, assessments and expenses of management the power of the said 'Trustees to sell said proprty shall cease, determine and be at an end. And they shall forthwith thereafter and with as little delay as the nature of the business will admit proceed to make partition of said premises and to lay off and divide the same in manner following, that is to say, they shall first divide the whole of said premises into two classes, viz. In the first class shall be embraced such portion of said property as may have becn laid off and reserved for the sites of towns, villages and cities, and of hydraulic privileges, and in the second class shall be embraced all the residue of the said property, and they shall thereupon divide each of the said sites of towns, villages, cities and hydraulic privileges embraced in the first class into forty eight parts of equal value, quantity and quality relatively considered. And the residue of said premises embraced in the second class shall be divided into forty eight parts of equal value, quantity and quality relatively considered, and the property thus divided and apportioned shall be distributed among the parties and persons interested in the proportions hereinafter stated; which distribution shall be made by the said 'Trustees for the time being by lot, so as to secure to each his just share in each class as above specified; and sixty days notice shall be given by the said Trustees to each of the parties interested of the time and place of such distribution. And upon such division they shall forthwith by good and sufficient deed or deeds release and convey in fee to the several persons and parties interested their heirs and assigns forever all the said residue of the said property in the shares and proportions following, that is to say, the said Joshua Aikin and George P. Shipman jointly nineteen forty eightl parts; to the said George P. Shipman in his own right two forty eighth parts; to the said Isaac Galland eight forty-eighth parts; to the said Edward C. Delavan four forty-eighth parts; to the said Samuel Marsh two forty-eighth parts; to the said Banjamin F. Lee three forty-eighth parts; to the said William E. Lee six forty-eighth parts; to the said Erastus Corning two forty-eighth parts; to the said Henry Seymour two forty-eighth parts. And the Trustees shall also at the same time divide among the said parties in the same propertion all the money securities for and evidences of debt which they may have on hand accruing from the said property or any part thereof.

Seventhly-It is understood that the said Aikin and Little shall not directly or indirectly during the continuance of these presents make 
any purchase of lands in said district of country on any other account, except by the consent of the Trustees for the time being until after the said fund of seventy-five thousand dollars shall have been fully invested by them, and if after that they shall make any purchase of the said lands, the parties hereto shall have the refusal thereof at cost on the terms and in the proportions herein expressed.

Eighthly-The said Trustees shall give to each one of the parties interested a certificate under the hands and seals of at least two of them one of whom shall be the President or chairman of the Board of Trustees, stating the interest which by virtue of these presents he is entitled to in the premises. And it is expressly agreed that if any assignment be made of any interest hereby created, the same shall be made on the said certificate which shall thereupon be surrendered to the 'Trustees at their office in the City of New York and a new certificate or certificates shall thereupon be issued therefor to the proprietor or proprietors; and no sale or transfer of any interest herein sliall be obligatory upon, or operate as a notice to the said Trustees of such assignment or transfer unless the above conditions be complied with, and the said parties who are designated and appointed 'Irustees for the objects and purposes herein expressed, do by these presents declare their assent to the said 'Trusts hereby created.

In testimony of their assents whereunto the said parties have hereunto set their hands and seals the day and year first above written

In the presence of-

Which said answer and schedule were endorsed as follows, to-wit: "Filed 8th May, A. D. 18.11.

o. S. X. Peck, Clerk.

Afterwards, to-wit, on the day and year aforesaid the following proceedings were had, to-wit:

Josiah Spaulding et al rs. Euphrosine Antaya et al. Partition.

In this case the said defendants having appeared by their counsel respectively and filed their answers to the petition and stated and produced their respective claims and exhibited their proofs of title and in some cases the original conveyances, and in others authentic copies of conveyances by which the same are held, and their said respective claims, and those of the petitioners by their counsel respectively being by consent submitted to the Court for adjudication and partition according to law, and the Court being satisfied by sufficient proof that the publications required by the act entitled an act to provide for the partition of real property have been duly made and no iother persons known or unknown having appeared and answered the said petition or produced or made any claim or any objection to said partition, and the said claims. of said parties now before the Court. Petitioners and Defendants and their respective proofs and conveyances being, by the Court heard and considered it is thereupon by the consideration of the Court, and with the consent of said parties this 8th day of May, 1841, ordered and ad- 
judged that the claims and rights of the said parties respectively to the undivided portions of the land mentioned and described in the said petition amounting in the whole to the number of one hundred and one equal portions, that of these defendants Marsh, Lee and Delavan 'Trustees for the clamants under the articles of association dated $22 \mathrm{~d}$ October, 1836, filed in this case, and as 'Trustees for the persons interested under said articles are entitled to forty one shares and five eighths of i share. The defendant, John Wright, is entitled to one-fourth of a share. The defendant, Cyrus Peck is entitled to one-eighth of a share. The defendant Samuel Abbott, and Abraham Wendall to one-half share. 'The defendant, William Phelps, to two shares. The defendant, Ebenezer D. Ayres, to one-half share. The defendant, William Gillis, is entitled to one share. The defendant, Henry McKee, is entitled to one share. 'The defendant, Wilson $\mathrm{L}$. Overall, is entitled to one share. The defendant, Garrett V. Deniston, is entitled to one-half share. The defendant, James L. Schoolcraft, is entitled to one-half share. The defendant, Elizabeth Hunt, is entitled to one share. The defendant, Rosella O. Gliem, is entitled to one share. 'The defendant, Mary L. Murdock, is entitled to one share. The defendant, Eliza O. Perkins, is entitled to one share. The defendant, James L. Burtis, is entitled to one share. 'The defendant, Margaret Farrar, is entitled to two shares. The defendant, James Muir, (H. T. Reid his guardian) is entitled to one share. The defendant, Thomas Connelly, is entitled to one share. The defendant, John C. Ward, is entitled to one-half share. 'I'he defendants, Abijah Fisher, David W. Kilbourne and Henry S. Austin, are entitled to one share. The defendant David W. Kilbourne and Henry Austin are entitled to one share. The defendant Edward Kilbourne is entitled to one-half share. T'he defendant John Bertram is entitled to one-half share. The defendant Edwin Manning is entitled to one-quarter of a share. 'l'he defendants Edwin Manning and Sheldon Norton are entitled to one-half share. The defendants Wright, McDaniel and Darrah are entitled to one share and three fourths. The defendants Manning and Hearn are entitled to one share. The defendant, Augustus Gonville is entitled to one share. The defendant, Benjamin Franklin Messenger is entitled to one share. 'The defendants the Heirs at law of Nathaniel Knapp are entitled to two shares and seven eighths of a share. The defendant Henry l3rowse is cntitled to one eighth of a share. The defendants John William and Dalzell Smith are entitled to two shares and one-half of a share. 'The defendant William H. Smith is entitled to two shares. The defendant John HI. Lines is entitled to one share. The defendant William Price is entitled to one share. The defendant Charles Thompson is entitled to one share and one equal share or undivided part is hereby reserved undivided among the other claimants for the defendant Euphrosine Antaya in case she should hereafter appear and prove the same, and that said petitioners are respectively entitled to the following shares and portions, to-wit: Josiah Spaulding is entitled to one share and three eighths of a share. Archi- 
bald Gamble is entitled to one share and one eighth of a share. Patrick Walsh is entitled to one full share. John and Edward Walsh are entitled to two full shares and seventeen one hundred and twentieth parts of a share. (Etienne Prevost is entitled to one half of a share): Heirs of Henry K. Ortley are entitled to two fifths of a share. Green Erskine is entitled to one full share and nineteen twenty fourths of a full share. Joseph Ridgway Trustee of George Patch one-third of a full share. Herman C. Cole is entitled to one fourth part of a full share. Stephen Gore is entitled to one eighth part of a full share. John B. Sarpy is entitled to one third of a full share. Edmund H. McCabc is entitled to one third of a full share. Hugh "Tumelty is entitled to one full share. James R. McDonald is entitled to one full share. Joseph W. Walsh is entitled to one full share. John O'Rourke is entitled to one half of a full share. Antoine Garcia and 'Margaret his wife onehalf share. Angelique La Guthrie now Mattabon is entitled to one half a full share. Michael Tesson is entitled to one full share. Heirs of Otis Reynolds eleven twenty fourtlss of a full share. Hcirs of J. A. H. Palmer one third of a full share. George H. Crossman five sixtlis of a full share. Antoine Le Claire is entitled to seven full shares. All of which said shares and portions of said parties, petitioners and defendants respectively are hereby by this Court and the authority thereof adjudged and decreed to be conrmed and their said shares and interests are heerby respectively confirmed accordingly. And it is hereby further ordered and decreed that partition be made according to the act aforesaid of the lands mentioned and described in the said petition cqually and fairly and impartially among the said parties, petitioners and defendants according to said act, and that the said partition be made according to the plat of the reservation of the Sac and Fox half breeds filed and agreed upon by the said parties in this case (Marked B) and that all other persons whatever shall be hereafter barred and concluded from any title or claim in said lands, and this Court does further appoint as Commissioners to make the said partition herein decreedSamuel B. Ayres, Harmon Booth and Joseph Webster with full power and authority to make the said partition into oneihundred and one shares of equal value and report the same to this Court, and to do all other acts in relation thereto authorized and required by the aforesaic act, and to make return of said partition of said shares and of their proceedings as required by said act to this Court for confirmation and such other and further proceedings as to the Court shall seem right and according to law.

It is further ordered and decreed that no partition shall be made under this decree of the land included in the Patent to Thomas F. Reddick described as follows, to-wit: Beginning bn the right and South Westerly lands (query bank) of the Mississippi (the most Northern corner of the survey) at a stone sixteen inches wide eighteen inches long and two inches thick, from which an elm twenty five inches in diameter bears South twenty seven degrees and fifteen minutes East 
distant two hundred and twenty seven links-And an elm twenty five inches in diameter bears South seventy nine degrees and thirty minutes East distant three hundred and thirty six links-Thence South thirty four degrees West, being the North Western boundary line of this survey at four chains and forty one links, the line between Sections three and ten (twenty four chains and thirty one links East of the quarter section corner) at fourteen chains and fifty nine links, leaves the inundated land and water at seventeen chains and fifty links, a road bears nearly East and West leading from the Barracks lying within this survey to Fort Madison from this point to the Old Pawnee village bears North sixty degrees West about three hundred yards, afterwards inhabited by the Sac Indians, also inhabited the place now occupied by the barracks on the East side of the creek which is South sixty at twenty nine chains and twenty links a branch thirty links wide runs South at forty four chains leaves the brush and scattering timber and enters smooth prairie bearingr East and West at sixty six chains and fifty links and old Indian trace bears South sixty degrees West and North sixty degrees East eighty eight chains and fifty links to a post the most Western corner of this survey in a mound in which are deposited three stones edges downwards one of which is eight inches square and two inches thick, and the two others about four inches square and two incles thick. Thence South fifty four degrees and fifteen minutes Fast being the South Western boundary line of this survey at seventecn chains and twenty three links intersects the line between sections ten and fifteen (thirty two chains and sixty links East of the corner of nine, ten, fifteen and sixteen at a post five inches in diameter in a mound five feet square at the bottom and two feet at top, under which mound are deposited three small stones cach about four inches square, one of them three inches, and the other two, two inches thick. At thirty one chains and fifty links a path bears North and South leading from St. Francisville to the aforesaid barracks at the head of the rapids of the Mississippi-At thirty nine chains a narrow valley runs along the foot of the bluff at 53 chains and 50 links leaves level prairie and enters the foot of the bluff at sixty chains and fifty links the top of the bluff at seventy six chains and thirty three links intersects the line between sections fourteen and fifteen five chains and twenty eight links North of the Quarter section corner on said line (at a post five inches in diameter two feet in the ground, from which an elm (old marked) ten inches in dianeter bears South fifty two degrees East distant onc hundred and sixty links and a hurr oak forked near the ground thirty inches in diameter bears South thirteen degrees East distant two hundred and eleven links cighty chains to a post eight inches in diameter (the most Southern corner of this survey) two fect in the ground, from which a burr oak (Marked S. 14 ' . $60 \mathrm{R} 5 \mathrm{~W}$ ) twenty five inches in dianeter bears North eighty one, degrees East distant seventy eight Jinks and an elm twenty five inches in diameter (marked with a notel and a blaze) bears North sixty four degrees and thirty minutes West distant one hundred and 
fifteen links. Thence North thirty four degrees East being the South Eastern boundary line of this survey at twenty five chains and ninety seven links a black oak twenty four inches in diameter leaves the prairie and enters scattering timber bearing East and West at thirty five chains and forty one links a black oak twenty five inches in diameter at forty four chains and fourteen links intersects the line'between Sections eleven and fourteen fifty two chains and eighty three links West of the corner of sections eleven, twelve, thirteen and fourteen at a post five inches in diameter from which an elm twelve inches in diameter bears South eighty three rlegrees and thirty minutes East distant forty one links and an elm ten inches in diameter bears North fifty five degrees East distant sixty eight links, at sixty two chains and seventy eight links a spring branch runs Westerly, at seventy nine chains and seventy eight links the top of the bluff bears East and West at eighty five chains and seventy eight links the foot of the bluff bears East and West eighty eight chains and fifty links to a stone thirty inches long sixteen inches wide and eight inches thick, three inches in the ground the edge in the direction of the line, being the most Fistern corner of this survey on the right and Southerly bank of the Mississippi from which Stone an Sim ten inches in diameter Marked P. S. bears North fifty eight degrees West three chains and fifty links, thence North sixty nine degrees West five chains at thirty links to a branch itwenty links wide runs from the South West, thence North eighty five degrees West at five chains and eighty links the right bank of a slough thence North sixty five degrees West at three chains and eighty seven links the left bank of the mouth of the slough into which a small branch flows from the South nine chains and seventy four links leaves timber extending Southward thence North fifty six degrees West at seven chains the Garrison the course of which is South seventy degrees West eleven chains nearly opposite the centre of the Garrison. Thence North thirty degrees West sixteen chains and fifty links at scven chains and twenty five links a stable one hundred links to the left which was formerly used by the soldiers of this station. Thence North fifty three degrees West six chains and fifty links to the South side of a slough or overflowed land at the mouth of a creek thence North twelve degrees West crossing the creek eleven chains and eiglat links to the place of beginning, Being in 'Jownship 66 North of Range 5 West of the' 5 th Principal Meridian, and being designated on the connected plat as survey numbered three thousand and ninety five until the further order of this Court without the consent of the Heirs of sicid Reddick.

Afterwards, to-wit, on the 31 st day of May $A$. D. 1841 the following proceedings were had, to-wit:

lerritory of Iowa

l.ee County $\}$ ss

Joseph Webster one of the Commissioners appointed by the decree of the District Court for said County dated May sth 1841 for the pur- 
pose of making partition of the lands in said decree mentioned according to said decree, being duly sworn, upon his oath deposes and says that he will honestly and impartially cxecute the trust reposed in him under said decrec.

Joseph Webster.

Sworn and subscribed before me this 31st day of May $\Lambda$. D. 1841. O. S. X. Peck Clerk Dist. Court.

Endorsed as follows, to-wit: Filed 31st May 1841. O. S. X. Peck, Clerk.

Territory of lowa

Lee County $\}$ ss

Samuel B. Ayres one of the Commissioners appointed by the decrec of the Dist. Court for said County dated May 8th $A$. D. 1841 for the purpose of making partition of the lands in said decree mentioned according to the said decree being duly sworn, deposes and says upon his oath that he will honestly and impartially execute the trust reposed in him under said decree. Subseribed and sworn before me this 31st day of May A. D. 184.1.

O. S. X. Peck, Clerk Dist. Court-Simuel B. Ayres.

Endorsed "Filed May 31. O. S. X. Peck, Clk.

'lerritory of Iowa?

Lee County $\int$ ss

Harmon Booth one of the Commissioners appointed by a decree of the District Court for said County dated May $8 \mathrm{~A}$. D. 1841 for the purpose of making a partition of the lands in said decree mentioned according to said decree being duly sworm deposes and says upon his oath that he will honestly and impartially execute the trust reposed in him under said decree.

Subseribed and sworn to before me this 31 st day of May 1841. O.S. X. Peck, D. C.

Endorsed "Filed May 3Ist 1841. O. S. X. Peck, Clerk.

Harmon Booth.

\section{HAWK EYE PUBLICAIION}

$\left.\begin{array}{l}\text { 'Territory of Iowa } \\ \text { I.ce County }\end{array}\right\}$ ss

Josialı Spaulding et al

Euphrosine Antayia et al $\}$

District Court or said County

April 'Term 1840

\section{Petition for Partition}

Notice is hereby given that a petition was filed on the 14th diay of April A. D: 1840 in the District Court of I ee County aforesiad by Josiah Spaulding, Archibald Gamble, latrick Walsh, Etienne Prevost, John and Edward Walsh, H. K. Ortley, Green Erskine, Joseph Ridyway assignce of George Patch, Herman C. Cole, Stephen Gore, John B. Sarpy, Edmunk H. MeCabe, Huglt Tumelty, James R. MeDonald, Jo- 
seph W. Walsh, John O'Rourke, Antoinne Garcia and Margaret his wife, Angelique Mattabon, formerly La Guthrie, Michael 'Tesson, Heirs and legal representatives of Otis Reynolds, deceased, Heirs and legal representatives of J. A. H. Palmer deccased, George H. Crossman and Antoine Le Claire as Petitioners and against Euphrosine Antaya, Elizabeth Hunt, Eliza O. Perkins, late Guildersleeve 'formerly Johnson, Mary L. Murdock, formerly Johnson, Rosella O. Gliem formerly Johnson, James Muir, Thomas Connelly, and Betsy Fatrar as defendants, and is now pending, wherein the said petitioners pray that a Partition be made of the following real estate, to-wit: All that tract of land commonly called the "Half Breed Tract" situate in Lee County aforesaid lying between the Mississippi and Des Moines rivers, bounded on the North by a line drawn from the North west, corner of the State of Missouri East to the Mississippi river, and containing one hundred and nineteen thousand acres more or less, and they the said defendants and all other persons interested in the property herein described are hereby required to appear and answer to the said petition on or before the first day of the next term of the District Court of Lec County aforesaid, to be begun and holden on the first Monday of October next, or the proceeding had in the cause thereafter will be binding and conclusive on them forever. Reid \& Jolnston, $\Lambda$ ttys. for Plaintiffs-John H. Lines, Clerk D. C.

$\left.\begin{array}{l}\text { Territory of Iowa } \\ \text { Des Moines County }\end{array}\right\}$ ss

I, James G. Edwards, Editor and Publisher of the "Hawkeye and Iowa Patriot" a public newspaper printed in Burlington in said 'lerritory do hereby certify that the notice which is hereto annexed was published in the said "Hawkeye and l'atriot" for twelve weeks successively and that the first publication thereof was mate on the 2d day of July A. D. 1840 .

Sworn to and subseribed before me Jumes G. Edwards, this 28 day of September A. D. 1841.

John S. Dunlap; Clerk Dist. Court of Des Moines County.

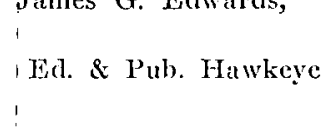

Afterwards, to-wit, at the Octoher 'Term of the Dist. Court of the first Judicial District for said County the following proceedings were hatd, to-wit:

'lerritory of Iowa ?

I.ec County $\}$ ss

At a District Court of the First Judicial District of said 'Territory begun and holden at the Court House in Fort Madison in said County on the (ith disy of October A. D. 184.1.

Present the Hon. Charles Mason, Judge.

Josiah Spaulding et al vs.

Euphrosine Antaya et al

Samuel 13. Ayres, IJarmon Booth and Josepl Webster the Commis- 
- ioners appointed by the decree made in this cause on the 8th day of May A. D. 1841 to make partition in the manner specified in said decree having this day presented their report bearing date at Fort Madison on the 4th day of October, 1841, whereby it appears that they have executed the duties of their appointment and have divided the land in the proceedings in this cause into one hundred and one equal shares excepting certain Islands in the rivers Des Moines and Mississippi which are so situated that partition thereof cannot be made without great prejudice to the owners thereof and have recommended that a sale of said Islands be made, and on hearing William Silliman and Hugh 'I'. Reid of Counsel for the parties in this cause and Orville $H$. Browning and Milton D. Browning of Counsel for certain persons not parties to this suit and by consent of all the parties to this suit and of their counsel, it is ordered, adjudgerl and decreed, and the Court by virtue of the power and iththority therein vested, doth order, adjudge and decree that the said report and all and singular the matters and things therein contained be, and the same hereby are ratified and confirmed; and it is further ordered, adjudged and decreed that the Clerk of this Court shall make the allotment of those shares pursuant to the Statute in such cases made and provided and that in making such allotment the said Clerk unite the fractions of shares mentioned in such report, in such manner as he may deem expedient, so that persons owning fractions of shares may together draw entire shares to be held by them in common in proportion to their respective fractional parts, and it is further ordered, adjudged and decreed that the partition made by such report, and which is to be perfected by the allotment of those shares, be firm and effectual forever.

And it is further ordered, adjudged and decreed that the said Commissioners sell at public auction to the highest bidder all the Islands situated in the Des Moines and Mississippi rivers in their said report mentioned except the Island called the "Cut off" situated in the river Des Moines within the jurisdiction of the State of Missouri. And that said Commissioners give notice of the time and place of said sale for the time and in the manner prescribed by law in respect to sales of land by Sheriff upon executions, that the said Commissioners sell said islands on a credit of one year as to two-thirds of the purchase money to be secured by the negotiable promissory notes of the purchasers and their mortgages of the property to be purchased by them respectively and as to the remaining one-third of the purchase money, that the same be paid in cash at the time of sale, and in default of the payment before mentioned the property be forthwith resold by the satid Commissioners without further noticc, and that before procecting to make such sale as aforesaid the said Commissioners give security pursuant to the Statute in such case made and provided. And it is further ordered, adjudged and decreed that the Clerk of this Court ascertain and report whether there be any general encumbrance by Mortgage, Judgment, Decree or otherwise upon any portion of the Islands so directed to be sold 
as aforesaid. And it is further ordered, adjudged and decreed that after completing such sale the said Commissioners shall report their proceedings to this Court, with a description of the different parcels of land sold to each purchaser and the price paid by him. And it is further ordered, adjudged and decreed that the cost and expenses of the proceedings in this cause, including the sum of nine hundred and ninety six (996) dollars for the costs and expenses of said Commissioners as specified by said report be paid in the first place by the petitioners and that the other parties reimburse to the said petitioners the respective proportions of the said parties of this suit costs and expenses in the ratio of their respective interests! within sixty days after the date of this decree, and that the said costs and expenses be deemed a lien on such interest until the same shall be paid, and that executions issue on behalf of the petitioners against such of the said defendants as shall omit to pay their respective proportions of said costs and expenses and the expenses of collecting the same, and it appearing that by some inadvertance and mistake the aggregate amount of the shares and fractions of shares in said decree mentioned is equal to one hundred and two shares and one third of a share that the number of shares provided for by the decree and report aforesaid is one hundred and one shares only, leaving one share and one third of a share unprovided for. It is by consent of all parties their attorneys and counsel further ordered that the said mistake be corrected by deducting from the portion awarded to the defendants Marsh, Lee and Delavan Trustees and the fractional part of five eighths of one share leaving the said Trustees the number of forty one full shares only and by deducting from the portion awarded to the defendant Antoine Le Claire five eighths of one share leaving to the said Le Claire six shares and three eightlss of a share only, and by deducting from the portion awarded to the defendant Green Erskine one twelfth part of a share leaving to said Erskine one share and seventeen twenty-fourths of one share only. Which said report of said Commissioners is in words and figures following, to-wit:

Territory of Iowa

County of Lec $\}$ ss

At a District Court of the first Judicial District of said Territory begun and holden at the Court house in Forti Madison in said County on the fourth Monday, to-wit, on the 26th day of $A$ pril $A$. D. 1841. Present Hon. Charles Mason, Judge. Among other were the following proceedings, to-wit:

Joseph Spaulding et al

Euphrosine Antaya et: al $\}$

Partition

In this case the said defendants having appeared by their Counsel respectively and filed their answers to the petition and stated and produced their respective claims and exhibited their proofs of titlc, and 
in some cases the original conveyances and in other authentic copies of conveyances by which the same are held and their said respective claims and those of the petitioners respectively by their counsel respectively being by Counsel submitted to the Court for adjudication and partition according to law, and the Court being satisfied by sufficient proof that the publication required by the act entitled "An Act for the Partition of Real Property" have been duly made, and no other person known or unknown having appeared and answered the said petition, or produced or madc any claim or any objection to said partition, and the said claims of the said parties now before the Court Petitioners and Defendants, and their respective proofs and conveyances being by the Court heard and considered, it is therefore by the consideration of the Court and with the consent of said parties this 8th day of May A. D. 1841, ordered and adjudged that the claims and rights of the said parties respectively to the undivided portions of land mentioned and described in said petition amounts in the whole to the number of one liundred and one equal portions. That of these the defendants Marsh, Lee and Delavan Trustees for the claimants under the Articles of Association dated Oct. 22d, 1836, filed in this case, and as 'Trustee for the persons interested under said articles are entitled to forty one shares and five eighths of a slatre. The defendant John Wright is entitled to one fourth of a share. 'The defendant Cyrus Peck is entitled to one eighth of a share. The defendant Samuel Abbott and Abraham Wendall are entitled to one lalf share. The defendant William Phelps is entitled to two shares. The defendant Ebenezer D. Ayres is entitled to one-half share. The defendant William Gillis is entitled to one share. the defendant Henry Mckee is entitled to one share. 'The defendant Garrett V. Deniston is entitled to one half share. The defendant Wilson Overall is entitled to one share. The defendant James I. Schoolcraft is entitled to one half share. The defendant Elizabeth Hunt is entitled to onc full share. The defendant Rosella $\mathrm{O}$. Gliem is entitled to one full share. 'The defendant Mary L. Murdock is entitled to one full share. 'The defendant Eliza O. Perkins is entitled to one full share. 'The defendant James L. Burtis is entitled to one full share. The defendant Margaret Farrar is entitled to two full shares. 'The defendant James Muir (Hugh 'T. Reid his guardian) is entitled to. one full share. 'The defendant 'Thomas Connelly is entitled to one share. The defendant John C. Ward is entitled to one half share. The defendants Abijals Fisher D. W. Kilbourne and Henry S. Austin are entitled to one share. 'The defendants D. W. Kilbourne and Henry S. Austin are entitled to one share. 'The defendant Edward Kilboume is entitled to one half silare. The defendant John Bertram is entitled to one half share. The defendant Edward Manning is entitled to one quarter of a share. The defendants James Manning and Sheldon Norton are entitled to me billf share. The defendants Wright, McDaniel and Darral are entitled to one slare and three fourths of a sharc: The defendants Manning and Hearn are entitled to one share: The defenclant Augustus Gonville is 
entitled to one share. The defendant Benjamin' Franklin Messenger is entitled to one share. The defendants Heirs at law of Nathaniel Knapp deceased, are entitled to two shares and seven eighths of a share. The defendant Henry Browse is entitled to one eighth of a share. 'The defendants William, John and Dalzell Smith are entitled to two shares and one half share. The defendant William H. Smith is entitler to two shares. The defendant John H. I.ines is entitled to one share. The defendant William Price to one share. The defendant Charles Thompson is entitled to one share, and one equal share or undivided part is hereby reserved among the other claimants for the defendant Euphrosine Antaya in case she should appear and prove the same. And that the said petitioners are respectively entitled to the following shares and portions of shares, to-wit: Josiah spaulding is entitled to one share and three eighths of a share. Archibald Gamble is entitled to one share, and one-eighth of a share. Patrick Walsh is entitled to one full share. Etienne Prevost is entitled to one-half a share. John and Edward Walsh are entitled to two shares and, seventeen one hundred and twentieth parts of a share. Heirs of Henry K. Ortley are entitled to two fifths of a share. Green Erskine is entitled to one full share and nineteen twenty-fourths of a share. Joseph Ridgway Trustee of George Patch is entitled to one third of a share. Herman C. Cole is entitled to one fourth of a full share. Stephen Gore is entitled to one eighth part of a full share. John B. Sarpy is entitied to one third of a full share. Edmund $H$. McCabe is entitled to one third of a full share. Hugh Tumelty is entitled to one full share. James R. McDonald is entitled to one full share. John O'Rourke is entitled to one half a full share. Joseph W. Walsh is entitled to one full share. Antoine Garcia and Margaret his wife are entitled to one half share. Angelique La Guthrie now Mattabon is entitled to one half share. Michacl 'Tesson is entitled to one full share. Heirs of Otis Reynolds are entitled to eleven twenty fourths of a share. Heirs of James A. H. Palmer are entitled to one third of a share. George $H$. Crossman is entitled to five sixths of a full share. Antoine Le Claire is entitled to seven full sharcs. All of which said shares and portions of said iparties, Petitioners and Defendants are respectively are hereby by this ;Court thereof adjudged and decreed to be confirmed and their said slatres and interests are hereby respectively confirmed accordingly. And it is hereby further ordered and decreed that partition be made accordingly to the act aforesaid of the lands mentioned and described in said petition equally and fairly and impartially among the said parties, Petitioners and Defendants according to said act, and that the said partition be made according to the plat of the reservation of the Sac and Fox half breeds filed and agreed upon by the said parties in this case (Marked B) and that all other persons whatever shall be hereafter barred and concluded from any title or claim in said lands, and this' Court doth further appoint as Commissioners to make the partition herein decreed Samuel B. Ayres, Harmon Booth and Joseph Webster with full powers and au- 
thority to make the partition into one hundred and one equal shares of equal value and report the same to this Court and to do all other acts in relation thereto authorized and required by the aforesaid act, and make return of said partition of said shares and of their proceedings as required by said act to this Conrt for confirmation and such other and further proceedings as they shall deem right and ascording to law. It is further ordered and decreed that no partition shall be made under this decree of the lands included in the patent to Thomas F. Reddick described as follows, to-wit. Beginning on the right and South West bank of the Mississippi River (the most Northern corner of this survey) at a stone sixteen inches wide eighteen inches long and two inches thick from which an elm twenty five inches in diameter beurs South twenty seven degrees and fifteen minutes East distant two hundred and thirty scven links, and an elm twenty five inches in diameter bears South seventy nine degrees and thirty minutes East distant three liundred and thirty six links, thence South thirty four degrees West being the North Westem boundary line of this survey, at four chains and forty one links the line between Sections three and ten, twenty four chains and thirty one links East of the quarter Section corner and fourteen chains and fifteen links leaves the inundated land and water, at seventeen chains and fifty links a road bears nearly East and West leading from the barracks lying within this survey to Fort Madison from this point the old Pawnee village bears North sixty degrees West about three hundred yards afterwards inhabited by the Sac Indians about the year Eighteen hundred and three, the Sac Indians also inlabited the place now occupied by the barracks on the East side of the creek which is south sixty degrees East of the point, about three hundred yards distant at twenty nine chains and twenty links a branch thirty links wide runs South at forty four chains leaves the brush and scattering timber and enters smooth prairie bearing East and West at sixty six chains and fifty links an old Indian trace bears South sixty degrees West and North sixty degrees East eighty eight chains and fifty links to a post the most Western corner of this survey in a mound in which are deposited three stones edge downward, one of which is eight inches square and two inches thick and the two others about four inches thick, thence South fifty four degrees fiftcen minutes least being the South Western boundary line of this survey at seventeen chains and twenty three links intersects the line between ten and fiften thirty two chains and sixty links Fast of the corner of Sections nine, ten, fifteen and sixteen at a post five inches in diameter in a mound five feet square at the bottom and two feet at top under which mound are deposited three small stones each about four inches square, one of them three inches and the other two, two inches thick, at thirty one chains and fifty links a path bears North and South leading from St. Francisville to the aforesaid barracks at the head of the rapids of the Mississippi at thirty nine chains a narrow vallcy runs along the foot of the bluff at fifty three chains and fifty links leares level prairie and enters the 
foot of the bluff at sixty chains and fifty links the top of the bluff at seventy six chains and twenty three links intersects the line between Sections fourteen and fifteen five chains and twenty eight links North of the quarter Section corner on said line at a post five inches in diameter two feet in the ground from which an Elm (old mark) ten inches in diameter bears South fifty two degrees Iast distant one hundred and sixty links and a burr oak forked near the ground thirty inches in dianeter bears South thirteen degrees East diștant two hundred and eleven links Eighty chains to a post eighty inches in diameter (the most: Southern corner of this survey) two feet in the ground from which a burr oak (marked S. 14, 'I. 66, R. 5 W. twenly five inches in diameter bears North eighty one degrees East distant severity eight links and an EIm twenty five inches in diameter (marked with a notch and blaze) bears north sixty four degrees and thirty minutes West distant one hundred and fifteen links; thence North thirty four degrees East being the South Eastern boundary line of this survey at twenty five chains and ninety seven links a black oak twenty four inches in diameter leave the prairie and enters scattering timber bearing East and West-At thirty five chains and forty one links a black oak twenty five inches in diameter, at forty four chains and fourteen links intersects the line between Sections eleven and fourteen fifty two chains and eighty three links West of the corner to Sections eleven, twelve, thirteen and fourteen at a post five inches in diamcter from which an elm twelve inches in diameter bears South eighty three degrees thirty minutes Wist distant forty one links and an elm ten inches in diameter bears North fifty five degrees East distant sixty eight links At sixty two chains and seventy eight links the top of the bluff bears East and West eighty eight chains and fitfy links to a stone thirty inches long sixteen inches wide and eight inches thick three inches in the ground the edge in the direction of the line being the most Eastern corner of this survey on the right and Southerly bank of the Mississippi from which stone an elm ten inches in diameter marked J. S. bears N'orth fifty eight degrees West three chains and fifty links. Thence North sixty nine degrees West five chains and twenty links a branch twenty links wide runs from the South West. Thence North eighty five degrees West at five chains and eighty links a slough thence North sixty five degrees West at three chains and eighty seven links the left bank of the mouth of the slough into which a small stream flows from the South nine chains and seventy four links leaves the timber extending southwardly. Thence North fifty six degrees West at seven chains the Garrison the course of which is South Seventy degrees West eleven chains nearly opposite the centre the Garrison. Thence North thirty degrees. West sixteen chains and fifty links at seven chains and twenty five links a stable one hundred links to the left which was formerly used by the soldiers of this station thence North fifty three degrees West six chains and fifty links to the South side of a slough in overflowed lands at the mouth of a creek thence North three degrees West crossing the creek eleven chains and 
eight links to the place of beginning until the further orders of this Court without the consent of the Heirs of said Reddick.

Trerritory of Iowa)

l.ee County $\}$ ss.

I hereby certify the foregoing to be a true and complete transcript of the record of the decree in the case of Josinh Spaulding and others versus Fuphrosine Antaya and others, for a partition of the half breed lands as fully and completely as the same remains of record in my office.

In Testimony whereof I hercto set my hand and affix the seal of the District Court for said County this 2d day of June 1841.

O. S. X. Peck, Clerk

The undersigned commissioners appointed to make partition of the Sac and Fox Half Breed Reservation situate in the County of Lee and l'erritory of Iowil, would report that in accordance with an order of the District Court of the County aforesaid in Chancery setting at the Octoher Term thereof 184.1, after having given legal notice proceeded to sell at public vendue on the 23d day of April 1842 at the Washington House in the town of Fort Madison to the highest bidder sundry islands in the Mississpipi River belonging to said Reservation, and among other sales sold to L. R. Reeves islands numbered One (1), Four (4) and Six (6) as appears on the plat hereunto annexed, containing sixty two and $80 / 100$ acres $(62-80 / 100)$ for the sum of Five Dollars and forty three cents (\$5.43). Also to Amos B. Tomlinson Island numbered Two (2) containing Twelve (12) acres at forty-five and a half cents per acre amounting to Five Dollars and forty six cents $(\$ 5.46)$. Also to A. N. Deming Island numbered Three (3) containing Twelve and a half acres $(12-1 / 2)$ at Nineteen and a half cents $(19-1 / 2)$ per acre amounting to Two Dollars and forty four cents $(\$ 2.44)$. Also Island numbered Five (5) to John Williams containing Twenty two and a half acres $(22-1 / 2)$ at twenty nine cents (29) per acre amounting to Six Dollars and forty two cents (\$6.42). Also to Levi Bracken Island numbered Seven (7) containing one hundred and eighty nine (189) acres, at Thirty seven and a half cents (37-1/2) per acre amounting to Seventy Dollars and Eighty eight cents (\$70.88). Also to Wilson Law and Arthur Morrison Island numbered Eight (8) containing Six hundred and Forty four acres (644) at Forty and a half cents (40-1/2) per acre, amounting to 'lwo hundred and Sixty Dollars and Eighty two cents (\$260.82). Also to Wilson Law and Arthur Morrison Island numbered Nine (9) containing Seven hundred and thirty four acres (734) at Twenty two and a half cents per acre (22-1/2) amounting to One hundred and Sixty five Dollars and Fifteen cents (165-15/100).

The above named Islands sold for the gross of Five hundred and Sixteen Dollars and Sixty cents (\$516-60/100) one-third of which amount was paid to us in hand and the remaining two-thirds to be secured by promissory notes of the purchasers with a mortgage upon 
the premises sold, payable the one-half in six months and the remaining sum in one year from and after the day of sale above mentioned.

We would also further report that the charges and expenses of examination of Islands meandering of river, assistants, boat hire, platting, stationery, sale and conveying amount to the sum of Ninety Five Dollars and Twenty five cents (\$95.25) which amount we have deducted from the amount paid to us and the balance of said sum is herewith returned to Court.

All of which we respectfully submit.

Fort Madison, April 28th, 1842.

$$
\left.\begin{array}{l}
\text { Sam'l B. Ayres } \\
\text { Harmon Booth }
\end{array}\right\} \text { Commissioners. }
$$

'Territory of Iowa

County of Lee $\}$ ss.

Be it remembered that on the Fourth day of May A. D. 1842, personally appeared beforc me Jocl C. Walker, Clerk of the District Court for said County, Samuel B. Ayres and Harmon Booth, Commissioners as aforesaid, who are to me personally known, who acknowledged the foregoing signatures to be genuine and were done in their official capacity.

In Testimony whereof, I have hereunto set my hand and affixed the seal of said court at my office in the town of Fort Madison this 4th day of May A. D. 1842.

(SEAL)

Joel C. Walker, Clerk D. C.

Territory of Iowa, District Court for the First Judicial District for Lee County. October 'Term 1841. October $7 \mathrm{th}, 1841$.

Josiah Spalding et al vs.

Euphrosine Antaya et al $\}$

Pursuant to the order made in this cause on the sixth day of the present month and the Statute in such case made and provided the Clerk of this Court now proceeds in open Court at the Court House in Fort Madison in said County to make allottment of the shares mentioned in said order by first numbering the shares corresponding with the numbers mentioned in the report of the Commissioners filed in this cause and with the numbers marked on the map or plat of the land to be divided annexed to said reports and then drawing the names of the corresponding after the manner of selecting a petit jury and the result of such allotment is as follows the names of the owners of the respective shares as the same shares are specified in said report and as their names were drawn by said Clerk being set opposite the names drawn by them respectively.

Share Number 1 was drawn by Marsh, Lee and Delevan, Trustees, etc.
" " 2 " " " William Phelps
" " 3 " " " Rosalie O. Giliem
6464
“ Marsh, Lee and Delevan, Trustees, etc. 


\begin{tabular}{|c|c|c|c|}
\hline " & " & 5 & "6 \\
\hline " & 46 & 6 & 66 \\
\hline " & 16 & a & x \\
\hline “" & "6 & $\tau$ & 16 \\
\hline "6 & 66 & 8 & 6 \\
\hline " & " & 9 & 66 \\
\hline " & 66 & 10 & " \\
\hline " & 66 & 16 & 16 \\
\hline " & " & 11 & G6 \\
\hline 6 & "6 & 12 & 6 \\
\hline
\end{tabular}

"Charles Thompson

"Patrich Walsh half share Ettienne Provost

"One-half share ..................

“ Marsh, Lee and Delevan, 'Trustees, etc.

" Marsh, Lee and Delevan, Trustees, etc.

" Marsh, Lee and Delevan, Trustees, etc.

" George H. Crossman five sixteenths of a share and

" The heirs of Otis Reynolds one sixth of a share

"William H. Smith

" John B. Sarpy one third of a share

Edmund $H$. MeCabe one third of a share

Heirs of J. A. H. Palmer one third of a full share

\begin{tabular}{|c|c|c|c|}
\hline d & “" & 13 & " \\
\hline$\therefore 6$ & " & 14 & “" \\
\hline " & " & 15 & "s \\
\hline "6 & " & 16 & “ \\
\hline "6 & " & 17 & " \\
\hline "6 & " & 18 & $" 6$ \\
\hline " & " & 19 & " \\
\hline " & "6 & 20 & " \\
\hline 《6 & " & 21 & “ \\
\hline "6 & “ & 22 & " \\
\hline s & " & 23 & " \\
\hline
\end{tabular}

“ Margaret Farrar

" John Walsh and Edward Walsh

"Wright MeDaniel and Darrah threefourths of a share

Edwin Manning one fourth of a share

" Marsh, Lee and Delevan, Trustees, etc.

" Marsh, Lee and Delevan, 'Trustees, etc.

"Henry S. Austin one-half share

John Bertram one half

"Thomas Connelly

"William Gillis

"Antoine Le Clare

" Marsh, Lee and Delevan, Trustees, etc:

"Josiah Spalding three eightlıs

A rchibald Ganble one eighth and

John William and Dalzell Smith one half share

" Marsh, Lee and Delevan, Trustees, etc.

" Marsh, Lee and Delevan, Trustees, etc.

"Greene Erskine seventeen twentyfourths, heirs of Otis Reynolds seven twenty-fourths

$\begin{array}{lllll}\text { " } & \text { " } & 27 & \text { " } & \text { " } \\ \text { " } & 28 & \text { " } & \text { " } \\ & 29 & \text { " } & \text { ، }\end{array}$

"Wright McDaniel and Darrah

" Marsh, Lee and Delevan, Trustees, etc.

"Abijah Fisher three fourths of a share $D$. W. Kilbourne one eighth

Henry S. Austin one eighth

\begin{tabular}{|c|c|c|c|}
\hline 68 & " & 30 & "6 \\
\hline & " & 31 & " \\
\hline & "6 & 32 & 66 \\
\hline
\end{tabular}

" Marsh, Lee and Delevan, Trustecs, etc.

" Mary L. Murdock

“ Marsh, Lee and Delevan, Trustees, etc. 
"William Phelps

“ James R. McDonald

" Marsh, I.ee and Delevan, 'Trustees, etc.

" Marsh, Lee and Delevan, 'I'rustees, etc.

“ John H. Lines

“ Joseph W. Walsh one half share

Angelique Mattabon one half share

" Patrick Walsh one half share

John O'Rourke one half share

“ Antoine LeClare

"Samuel Abbott and Abraham Wendall one half of ai share

James L. Schoolcraft one half share

"Josiah Spalding

" Marsh, Lee and Delevan, Trustees, etc.

"Wilson Overall

" Marsh, Lee and Delevan, 'Trustees, ete.

" John and Edward Walsh

"Marsh, Lee and Delevan, Trustees, etc.

“ Marsh, Lee and Delevan, Trustees, etc.

" Henry McKee

“ Euphrosine Antaya

“ Margaret Farrar

" Manning \& Hearn

"Heirs of H. K. Ortley three fifths of a share, Herman C. Cole one fourtls of a share, Joseph Ridgway trustee of George Patch one third of a share

"John William and Dalzell Smitlı

“ Marsh, Lee and Delevan, Trustees

" Marsh, Lee and Delevan, 'Trustees

“Joseph W. Walsh one half share Antoine Garcia and wife one half share

" Hugh Tumelty!

"John C. Ward 'one half of share Garret V. Deniniston one half share

“ James Manning and Sheldon Norton one half share

Ebenezer D. Ayres one half share

" The heirs at law of Nathaniel Knapp

" Marsh, Lee and Delevan, Trustees, etc.

“ Marsh, Lee and Delevan, Trustees, etc.

“ David W. Kilbourne one half share Edward Kilbourne one half share

“ Marsh, Lee an $\not$ Delevan, Trustees, etc.

"Marsh, Lee and Delevan, Trustees, etc.

" Elizabeth Hunt 


\begin{tabular}{|c|c|c|c|}
\hline "6 & " & 68 & " \\
\hline "6 & "6 & 69 & " \\
\hline "6 & “ & 70 & " \\
\hline "، & " & 71 & " \\
\hline "6 & "6 & 72 & "s \\
\hline 46 & " & 73 & " \\
\hline "6 & "6 & 74 & "6 \\
\hline$" 6$ & " & 75 & "6 \\
\hline 66 & " & 76 & $"$ \\
\hline 6 & $"$ & 77 & "6 \\
\hline "6 & " & 78 & " \\
\hline 6 & " & 79 & " \\
\hline "6 & " & 80 & " \\
\hline$" 6$ & " & 81 & " \\
\hline$"$ & " & 82 & " \\
\hline " & $" 6$ & 83 & $"$ \\
\hline "ब & " & 84 & "6 \\
\hline " & " & 85 & " \\
\hline “6 & " & 86 & “ \\
\hline
\end{tabular}

"Joln William and Dalzell Smith

" Marsh, Lee and Delevan, Trustees, etc.

" The Heirs at law of Nathaniel Knapp

" Eliza O. Perkins

" Greene Erskine

" Marsh, Lee and Delevan, Trustees, etc.

" Benjamin Franklin Messenger

" Marsh, Lee and Delevan, Trustees, etc.

" Marsh, Lee and Delevan, T'rustees, etc.

"Antoine Le Clare

"Marsh, Lee and Delevan, Trustees, ctc.

" James Muir (H. S. Reid Guardian)

"Antoine Le Clare

"Augustus Gonville

" Marsh, Lee and Delevan, 'Trustees, etc.

"Marsh, Lee and Delevan, 'Trustees, etc.

" Marsh, Lee and Delevan, 'Trustees, etc.

"William Price

"The Heirs at law of Nathaniel Knapp seven eighths of a share

Henry Browse one eighth of a share

"Antoine Le Clare three eighths of a share, John Wrights one fourth of a share, Cyrus Peck one eighth of a share, Stephen Gore one eighth of a share, John and Edward Walsh one eighth of a share

\begin{tabular}{|c|c|c|c|}
\hline “ & " & 88 & " \\
\hline " & “ & 89 & " \\
\hline "s & 16 & 90 & " \\
\hline " & " & 91 & " \\
\hline " & " & 92 & " \\
\hline “ & " & 93 & " \\
\hline " & "6 & 94 & " \\
\hline " & "6 & 95 & 6 \\
\hline " & " & 96 & " \\
\hline " & $"$ & 97 & " \\
\hline " & " & 98 & " \\
\hline " & " & 99 & " \\
\hline " & " & 100 & " \\
\hline & " & 101 & \\
\hline
\end{tabular}

" Marsh, Lee and Delevan, 'Trustees, etc.

" Marsh, Lee and Delevan, 'Trustees, etc.

" Michael Tesson

" Marsh, Lee and Delevan, 'Irustees, etc.

" Marsh, Lee and Delevan, Trustees, etc.

" Marsh, Lee and Delevan, 'lrustees, etc.

" Antoine Le Claire

"Archibald Gamble

" Marsh, Lec and Delevan, Trustees, etc.

" Marsh, Lee and Delevan, 'l'rustees, etc.

"Antoine I.e Claire

"James L. Burtis

"William H. Smith

" Marsh, Lee and Delevan, Trustees, etc.

Whereupon the drawing and allottment above mentioned having been completed in manner aforesaid with the result aforesaid, on the motion of William Silliman of Counsel for certain of the parties and by consent and by consent of all the other parties to this suit; It is ordered, adjudged and rlecreed and this Court doth order, adjudge and decree that the above drawings and allottment be confirmed and that the parties 
hold the shares whose numbers are opposite their respective names in manner aforesaid and that the partition made in this cause be firm and effectual forever.

STA'TE OF IOWA

LEE COUN'TY $\}$ SS.

I, O. R. Johnston, clerk of the District Court of the state of Iowa, in and for said county, do hereby certify that the above and foregoing is a true and perfect transcript of certain proceedings of the District Court of Lee County as set out therein, now on file in the office of the clerk of the District Court of Lee County, at Keokuk, in the above entitled cause as fully as the same remains on record in $\mathrm{my}$ office.

IN TESTIMONY WHEREOF, I have hereunto set my hand and affixed the seal of said court, at my office in the city of Keokuk, in said county, this twentietl day of March, A. D. 1920'.
[L. S.]
O. R. Johnston, Clerk of the District Court. By Mary Vollers, Deputy.

$\left[\begin{array}{r}1 \\ \vdots \\ \vdots\end{array}\right.$

\section{SALE OF LO'TS.}

We find in the last Reporter a notice from the commissioners appointed to locate a new Seat of Government, that a sale of lots will commence on Thursday, the 28th of October, at Monroe city, the newly located seat of Government. The terms are as follows: One fourth of the purchase money to be paid in hand at the sales, the ballance in three equal enstallments to two, four and six years, to bare interest at the rate of six per cent per annum, from the date of said sale until paid. The sale, will be continued from day to day, until all the lots intended to be sold at said sale are offered-Weekly Miners' Express, Dubuque, Iowa, September 29, 1847. (In the newspaper collection 'of the Historical, Memorial and Art Department of Iowa.). 
Copyright of Annals of Iowa is the property of State of Iowa, by \& through the State Historical Society of Iowa and its content may not be copied or emailed to multiple sites or posted to a listserv without the copyright holder's express written permission. However, users may print, download, or email articles for individual use. 